\title{
Sjølvmord, smitte og 13 Reasons Why
}

\author{
Av Åse Lundegaard Mattson
}

\section{SAMMENDRAG}

I 2017 skjedde det uvanleg mange sjølvmord og sjølvmordsforsøk både i Trondheim og i Lillehammer. Trondheim kommune set sjølvmordsåtferda i samanheng med tv-serien 13 Reasons Why. Sjølvmord er eit tema som vekker sterke kjensler, og mange er bekymra for å gjere noko som fører til potensiell smitte. Denne artikkelen er ei usystematisk litteraturgjennomgang som belyser tema smitte, og eg forsøkjer å svare på spørsmålet «Er det noko med tv-serien 13 Reasons Why som potensielt kan fremme sjølvmordståferd hos ungdom?» i lys av forskingslitteraturen. Artikkelen viser òg til verktøy ein kan nytte for å førebyggje smitte og følgje opp ungdom ein er bekymra for.

There was an unusually high number of suicides and suicide attempts in Trondheim and Lillehammer in 2017. In Trondheim municipality the increased activity in suicidal behavior seemed to be connected to the series 13 Reasons Why. Suicide is a topic that brings about strong feelings, and worries about clusters are common following the suicide of an adolescent. This article is a non-systematic literature review that seeks to shed some light on suicide clusters. Using the literature, I will attempt to answer the question «Are there characteristics of the TV-series 13 Reasons Why that could potentially promote suicidal behavior in adolescents?» The article will also suggest tools that can be used in the prevention of clusters, and some interventions.
I MAI 2017 kunne ein lese i VG at kommunalsjefen i Trondheim var bekymra for ein uvanleg høg førekomst av sjølvmordsåtferd og sjølvmord (Misje \& Wold, 2017). Fleire av ungdomane har fortalt vaksne rundt seg at dei har sett serien 13 Reasons Why, som handlar om ei 17 år gamal jente som tek sitt eige liv. Kommunen er bekymra for ein mogleg smitteeffekt, og sender ut eit brev med oppmoding til foreldre som har born i grunnskulen om å bry seg, støtte born og unge rundt seg, samt informasjon om kor ein kan få hielp. Same månad melder VG at det i Lillehammer har skjedd tre siølvmord og eit siølvmordsforsøk blant elevar i vidaregåande skule, i løpet av kort tid (Røed, 2017). Lillehammer kommune set ikkje saken i samanheng med det som har skjedd i Trondheim eller med Netflixserien, men dei er bekymra for smitte.

I kraft av mi stilling som psykolog ved Ressurssenter om vald, traumatisk stress og sjølvmordsførebygging (RVTS) har eg kurs om sjølvmordsførebygging for helsepersonell, og får ofte spørsmål om smitte. Siølvmord er eit tema som vekker sterke kjensler, og mange er redde for å giere vondt verre dersom ein gier noko feil. Når det har vert tilfelle av potensiell smitte blir mange ekstra bekymra, og mange vegrar seg i ennå større grad for å ta i temaet. Denne redsla kan i verste fall 
Ferguson (2019) med at dei overordna resultata «[...] did not support a relationship between fictional media portrayals of suicide and suicide behaviors, thoughts or depressed mood among consumers» ( $\mathrm{r}=.034$, ns) (s. 1182). Han finn ein signifikant smitteeffekt av studiar som baserer seg på data på gruppenivå $(p=.016)$, bivariate korrelasionsstudie $(\mathrm{p}=.001)$ og studie om heavy metal (p .o15), men effektstorleikane er jamt over små (hhv. r =.101, .234 og .o99), og blir mindre når ein korrigerer for publikasionsbias (hhv. r $\chi=.077$, .049 og .023). Ferguson peiker på at studiar som har undersøkt smitte i stor grad baserer seg på pre-post studie med data på gruppenivå eller spørjeundersøkingar, som begge har sine metodologiske utfordringar. Det er til dømes vanskeleg å kontrollere for alle utanforliggande variablar i både spørjeundersøkingar og i pre-post studiar. Dette er eit krav for å påvise ei årsakssamanheng mellom det å bli eksponert for tematikken siølvmord og ei auke i sjølvmordsåtferd. Ferguson peiker òg på moglege tredje variablar som ei utfordring i feltet: ein kan t.d. tenkje seg at dei som er meir opptekne av tema siølvmord, eller som er siølvmordsnære, i større grad søkjer ut medium som omhandlar tema. Ein anna utfordring er at studie som påviser ei korrelasjon mellom eksponering for sjølvmord og auke i siølvmordsåtferd kan ha fanga opp tilfeldige variasionar i sjølvmordstal.

I ein artikkel om smitte på undergrunnen i Wien, viser Etzersdorfer og Sonneck (1998) til fleire studiar som har påvist ein assosiasion mellom sjølvmord i massemedia, i fiksjon, og drap, og ei auke i åtferd $\mathrm{i}$ kort tid etterpå. Forfattarane påpeiker at «dei fleste av dei ovanfornemnde studiane starta etter auka i siølvmordsåtferd eller antok at imitasjonsåtferd hadde skjedd, og forsøkte retrospektivt å finne ei imitasjonseffekt» (s.68, eigen omsetjing). Det kan dermed tenkast at mange av døma ein har på smitte baserer seg på lite representative medieframstillingar. I denne samanheng ynskjer eg å trekke fram at det sjølv om det finst ei rekke studiar som har dokumentert ein assosiasion mellom eksponering for siølvmord (anten i massemedia, i fiksion eller giennom geografisk eller sosial nærleik) og ei påfølgande auke i siølvmordsåtferd, så finst det òg ei rekke studiar som ikkje finn den same assosiasjonen, eller til og med finn at media kan ha ei positiv påverknad på sjølvmordsåtferd (sjå mellom anna Ferguson, 2019, s.1180; Gould, Wallenstein \& Davidson, 1989; Gould, Jameson \& Romer, 2003; Haw, Hawton, Niedzwiedz, \& Platt, 2013; Niederkrotenthaler et al., 2012; Ystgaard, 1997; Sinyor et al., 2018; Stack, 2005, for forskingsoppsummeringar av kva som kan hemme og fremme smitte). Ferguson påpeiker òg dette i si metaanalyse: «It may be that there are some incidents in which studies appear to rise after one show, but do not after another, or even appear to decline (indeed, the full record of aggregate studies supports this pattern).» (s. 1184). Eg kjem til å drøfte studie som har forsøkt å

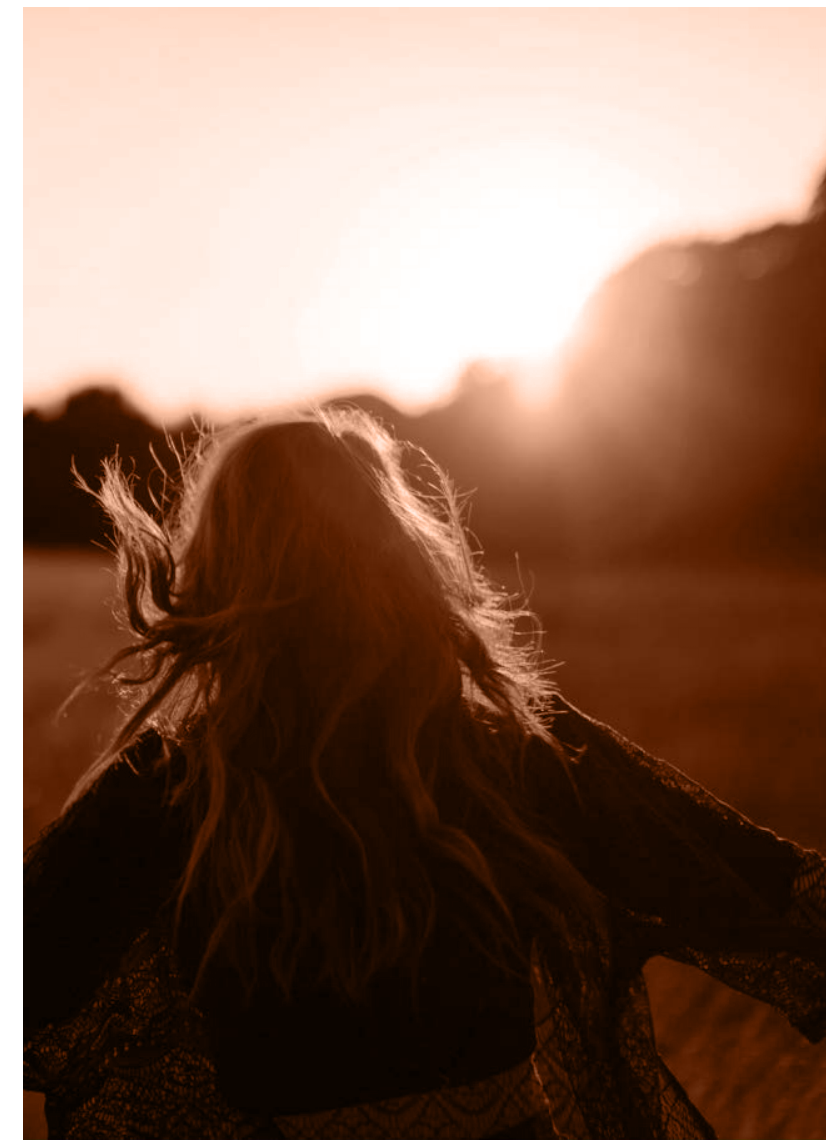

forklare desse kontrasterande funna i meir detalj i avsnittet «Siølvmord og smitte i media: mass clusters».

Ei anna utfordring innanfor fagfeltet er at ein ikkje har einast om ein definision av kva smitte er. I ein review av lokalt avgrensa smittefenomen (såkalla point clusters) påpeiker Niedzweidz et al. (2014) at det finst lite forsking på fenomenet, og at forskinga som finst er prega av ein manglande eintydig definisjon av smitte. Av studiane Niedzweidz et al. undersøkte, hadde mindre enn ein tredjedel definert smitte, og det var stor grad av variasjon i dei ulike definisjonane. Det var variasjon i tidsperioden ein undersøkte, samt korleis ein avgrensa smitteeffekten geografisk. Det var òg variasjon i talet siølvmord ein inkluderte i eit cluster, og om ein berre såg på giennomførte siølvmord, eller òg inkluderte annan sjølvmordsåtferd. Dette gier det utfordrande å konkludere om ei auke i sjølvmord etter eksponering for tematikken er smitte.

Samla sett gier desse metodologiske utfordringane at det - som Ferguson (2019) påpeiker - er viktig at «[...] individuals exercise caution in public statements linking suicide-themed fictional media to suicide contaigon as data may not be able to support such claims» (s. 1178). I denne artikkelen kjem eg likevel til å trekke fram element ved tv-serien 13 Reasons Why, 
som eg med grunnlag i eksisterande litteratur tenkjer kan fremje smitte. Eg ynskjer å understreke at det ikkje betyr at eg hevder at det er ei årsakssamanheng mellom det å ha sett serien og eventuell siølvmordsåtferd hos sårbar ungdom. Ein kan heller ikkje trekke slutningar om årsakssamanheng i ein enkeltsak på bakgrunn av data på gruppenivå. Men siølv om ein ikkje har påvist ei årsakssamanheng tenkjer eg det, i lys av dei mange assosiasjonane ein har funnet i litteraturen (sjå avsnitta under), samt eigne erfaringar som psykolog ved RVTS Vest, er god grunn til å behandle smitteproblematikken som eit reelt fenomen, og ta den på alvor. Dette betyr mellom anna å ta høgde for at sårbar ungdom kan bli negativt påverka av å sjå denne serien, ha gode rutinar for å fange dei opp, vere trygg nok til å kunne snakke om temaet, samt å kunne gie hielp der ein tenkjer det er naudsynt.

\section{To typar smitte: mass- og point clusters}

Det finst etterkvart mykje forsking som viser ein samanheng mellom enkelte typar eksponering for siølvmord og ei auke i førekomst kort tid etter denne eksponeringa (sjå mellom anna Gould, Wallenstein \& Davidson, 1989; Gould, Jameson \& Romer, 2003; Haw, Hawton, Niedzwiedz, \& Platt, 2013; Niederkrotenthaler et al., 2012; Ystgaard, 1997, Sinyor et Al., 2018; Stack, 2005, for oppsummeringar). Innanfor forskinga har ein skilt mellom to ulike smittefenomen: såkalla mass- og point clusters. Ved mass clusters ser ein ei opphoping av sjølvmord i kort tid etter sjølvmord har vert tematisert i media (Niederkrotenthaler et al., 2012; Stack, 2005). Ved point clusters er det snakk om ein meir lokalt avgrensa smitteeffekt, der det skjer uvanleg mange sjølvmord i løpet av relativt kort tid, innanfor same geografiske område eller innanfor same sosiale omgangskrins (Gould et al., 1989; Haw et al., 2013; Niedzweidz et al., 2014; Robinson et al., 2016; Swanson \& Colman, 2013). I den neste delen av artikkelen vil eg giere greie for forskinga på desse to typane smittefenomen, samt skildre faktorar ein antar hemmar og fremmar smitte. Eg vil òg giere greie for teoriar om korleis sjølvmord smittar, samt kven ein har funnet å vere mest sårbar for smitteeffektar.

\section{Sjølvmord og smitte i media: mass clusters}

Det finst fleire døme på at media kan vere ein viktig aktør både når det gield å auke og redusere førekomsten av siølvmord. Det finst mellom anna fleire døme på medieomtale av kjendisar som tek livet sitt (Stack, 2005; Niederkrotenthaler et al., 2012), spesifikke sjølvmordsmetodar (Etzersdorfer, Voracek \& Sonneck, 2001; Marzuk et al., 2015) og plassar der fleire tek livet sitt (Bateson, 2012; Etzersdorfer \& Sonneck, 1998), som kan føre til ei auke i sjølvmord kort tid etter medieomtalen, samt at fleire dreg til same stad eller vel same metode. Ein av dei forste omtalane av fenomenet smitte finn ein hos Phillips (1974), som skildra den såkalla Werther-effekten, kjent som imitasjonssiølvmord. For meir enn 200 år sidan skreiv Goethe boka «Den unge Werthers lidelser», der hovudpersonen Werther tek sitt eige liv. I kjølvatnet av denne boka tok ein rekke unge menn livet sitt på same måte som Werther. Mange av dei hadde kledd seg i liknande klede, og ein fann eksemplar av boka hos avdøde.

Eit anna døme på dette er talet på siølvmord i undergrunnen i Wien på 8o-talet (Etzersdorfer \& Sonneck, 1998). Når undergrunnen først opna vart den ifølgie Etzersdorfer og Sonneck sett på som ein akseptabel måte å ta sitt eige liv på, samtidig som at media omtalte desse siølvmorda hyppig, på ein dramatisk måte. Den austerrikske foreining for sjølvmordsforebygging utvikla retningslinjer for å omtale sjølvmord i media, samtidig som ein satt i gang ein siølvmordsførebyggande mediekampanje i midten av 1987. Dette førte til at media endra sin måte å rapportere sjølvmorda på, og ein såg ein 84,2 prosent nedgang i siølvmord på undergrunnen i andre halvdel av 1987 (frå n = 19 til $n=$ 3). Ein fann ingen auka bruk av andre metodar under forskingsperioden, og forskarane konkluderer med at den mest sannsynlege forklaringa for nedgangen i siølvmord og sjølvmordforsøk er endringa i medierapportering. Etter den skarpe nedgangen heldt tala seg stabilt lave fram til 96.

Det finst fleire døme på at omtale av sjølvmord i media er assosiert med ei auke i sjølvmord i kort tid etter medieomtale (Niederkrotenthaler et al., 2012; Stack, 2005). I ei metaanalyse av sjølvmord hos kjendisar i media fann Niederkrotenthaler et al. (2012) ei lita auke (effektstørrelse på o.26) i siølvmord ein månad etter medieomtale, samanlikna med månaden før. Effekten auka når ein knyta reportasjen opp mot regionen siølvmordet skjedde i (o.64 for Nord Amerika, 0.58 for Asia, 0.36 for Australia og o.68 for Europa). Niederkrotenthaler et al. (2010) fann liknande effektar for region i sin studie av austerrikske avisartiklar om sjølvmord.

Det finst òg evidens for at ansvarleg medieomtale av sjølvmord kan førebygge sjølvmord (Gould et al., 2003; Niederkrotenthaler et al., 2010; Stack, 2005), samt fremme hielpsøkeåtferd (Sinyor et al., 2018). Forskarar har undersøkt kvifor enkelte typar medieframstilling av sjølvmord er assosiert med ei auke i sjølvmord, medan andre typar framstilling ikkje forer til ei auke, og i enkelte tilfelle til og med kan føre til ein reduksjon i siølvmordstal, eller ei auke i hjelpsøkeåtferd. I sin review av reportasjar om sjølvmord i media, fann Stack (2005) at ekte historier om siølvmord, særleg sjølvmord 
hos kjendisar i underhaldningsbransjen og politikarar, hadde større sannsyn for imitasjonseffekt enn fiksjonelle framstillingar. Han fant òg at dersom reportasien fokuserte på negative aspekt av sjølvmordet (t.d. fysiske konsekvensar av siølvmordshandlinga eller smerte, å framheve at siølvmord er galt, eller trekke fram løysingar og alternative handlingsmønstre til sjølvmord) minka sannsynet for imitasjonseffekt med $99 \%$. Liknande konklusjonar finn ein i ei studie av avisartiklar i 13 større aviser som vert distribuert i Toronto frå 2011-2014 (Sinyor et al., 2018). Desse forfattarane fann ei samanheng mellom auke i sjølvmord 7 dagar etter publikasjon, og artiklar der ein skildra sjølvmordet som

\section{Det er konsensus i nasjonale og internasjonale retningslinjer om at å presentere noktern kunnskap om sjølvmord, samt råd om kor ein kan få hjelp, ikkje er assosiert med ei auke $i$ sjølvmord.}

uunngåeleg, ved sjølvmordsmetodane kveling (unntatt ved kvelding med eksos) og hopping, i artiklar der ein skreiv om siølvmordspaktar, eller der ein hadde ei overskrift som inkluderte metoden. Dei fann ei reduksjon i sjølvmord for artiklar der ein inkluderte ugunstige trekk, der ein nemnte metodane jernbane, kutting eller stikking, eller der ein skreiv om mord-sjølvmord.

Niederkrotenthaler et al. (2010) analyserte 497 avisartiklar i austerriksk media i ein halvårsperiode, og fann at reportasjar om sjølvmordstankar utan påfølgiande sjølvmordsåtferd, der ein framheva korleis ein kunne mestre kriser, var assosiert med ei nedgang i sjølvmord veka etter reportasjen. På den andre sida fann dei at artiklar der ein presenterte ekspertkommentarar og epidemiologisk kunnskap om sjølvmord, hang saman med ei auke i sjølvmord. Det er konsensus i nasjonale og internasjonale retningslinjer om at å presentere nøktern kunnskap om sjølvmord, samt råd om kor ein kan få hjelp, ikkje er assosiert med ei auke i sjølvmord (Helsedirektoratet, 2017). Presseetiske retningslinier anbefaler at ein både presenterer fakta om siølvmord og kor ein kan få hjelp i reportasjar om tema (Norsk Presseforbund, 2006; World Health Organization, 2008). Dette funnet ser dermed ut til å så tvil om desse anbefalingane, men i ein vidare analyse av materialet fant ein at artiklar som innehaldt ekspertkommentarar og epidemiologisk kunnskap om sjølvmordsførebygging i større grad innehaldt element forbunde med sensasjonalistiske og tabloidiserte framstillingar av sjølvmord. Forskarane fant at særleg reportasjar som innehaldt epidemiologisk kunnskap om sjølvmord hadde ei høg grad av innhald skildra som skadeleg i presseetiske retningslinjer. Forfattarane skriv at «expert opinions seem to be used as a means of giving an air of seriousness to reporting, but at the same time tend to be embedded in an unfavorable, sensationalist context» (s. 241). I desse artiklane brukte ein statistikk om sjølvmord på ein tabloid måte. Den negative effekten av ekspertkommentarar og epidemiologisk kunnskap kan dermed skuldast ei samanblanding av skadeleg og beskyttande materiale, heller enn ekspertkommentarane og den epidemiologiske kunnskapen om sjølvmord sjølv.

Det er òg funne smitteeffektar av fiksjonelle framstillingar av sjølvmord i media (sjå t.d. Gould, Jameson \& Romer, 2003, s. 1271-1272). I ei studie av paracetamoloverdose etter ein episode av tv-programmet Casualty, fann Hawton et al. (1999) ei 17 \% auke i paracetoverdosar i britiske legevaktar og psykiatriske teneste i veka etter tv-programmet giekk på lufta, og $9 \%$ auke veka etter. Forskarane interviua 32 pasientar som oppsøkte helsehjelp grunna paracetoverdose den første veka etter programmet. Tjue prosent sa at programmet hadde påverka avgierda deira om å ta ei overdose, og $17 \%$ sa det hadde påverka valet av metode. I ei metaanalyse av smitte frå fiksjonelle framstillingar av siølvmord konkluderte imidlertidig Ferguson at data ikkje støtter teorien om at fiksjonelle framstillingar av sjølvmord smittar (2019). Ferguson påpeiker mellom anna sprikande funn når det gield smitte, men det er viktig å merke seg at han ikkje har giort ei analyse av innhaldet i dei ulike framstillingane av sjølvmord. Dette ville vert interessant for å sjå om ein finn ei liknande effekt som Stack (2005) og Sinoyr et al. (2018) som ein fann mellom reduksion i siølvmord og fokus på negative eller ugunstige karakteristika i reportasjane om temaet. Det er behov for å replisere desse funna, samt å undersøke nærmare kva faktorar som hemmar og fremmer sjølvmordsåtferd etter at temaet har vert i media.

\section{Sjølvmord og smitte i lokalsamfunn: point clusters}

Ein anna type smitteeffekt er når eit siølvmord i eit lokalsamfunn eller eit geografisk avgrensa område, fører til fleire siølvmord eller meir sjølvmordsåtferd kort tid etter det første dødsfallet. I nyare forsking har ein utvida konseptet om geografisk nærleik til å inkludere sosial nærleik (sjå mellom anna Niedzweidz et al., 2014). Tilgangen til internett og sosiale medium gier at mange unge som slit kan finne kvarandre over store avstandar. I jobben min kjem eg i kontakt med hielparar som fortel om ungdom som deler erfaringar med og bilete av sjølvskading, sjølvmordsforsøk, og i enkelte tilfelle giennomførte sjølvmord, med kvarandre giennom sosiale media. Sjølvmordsåtferd og siølvmord kan dermed ha konsekvensar langt utover lokalsamfunnet. Av denne grunn anbefaler Niedzweidz et al. (2014) at ein brukar følgiande definisjon frå Larkin og Beatrais (2012): «a series of three or more closely grouped deaths within 3 months that can be linked by space or 


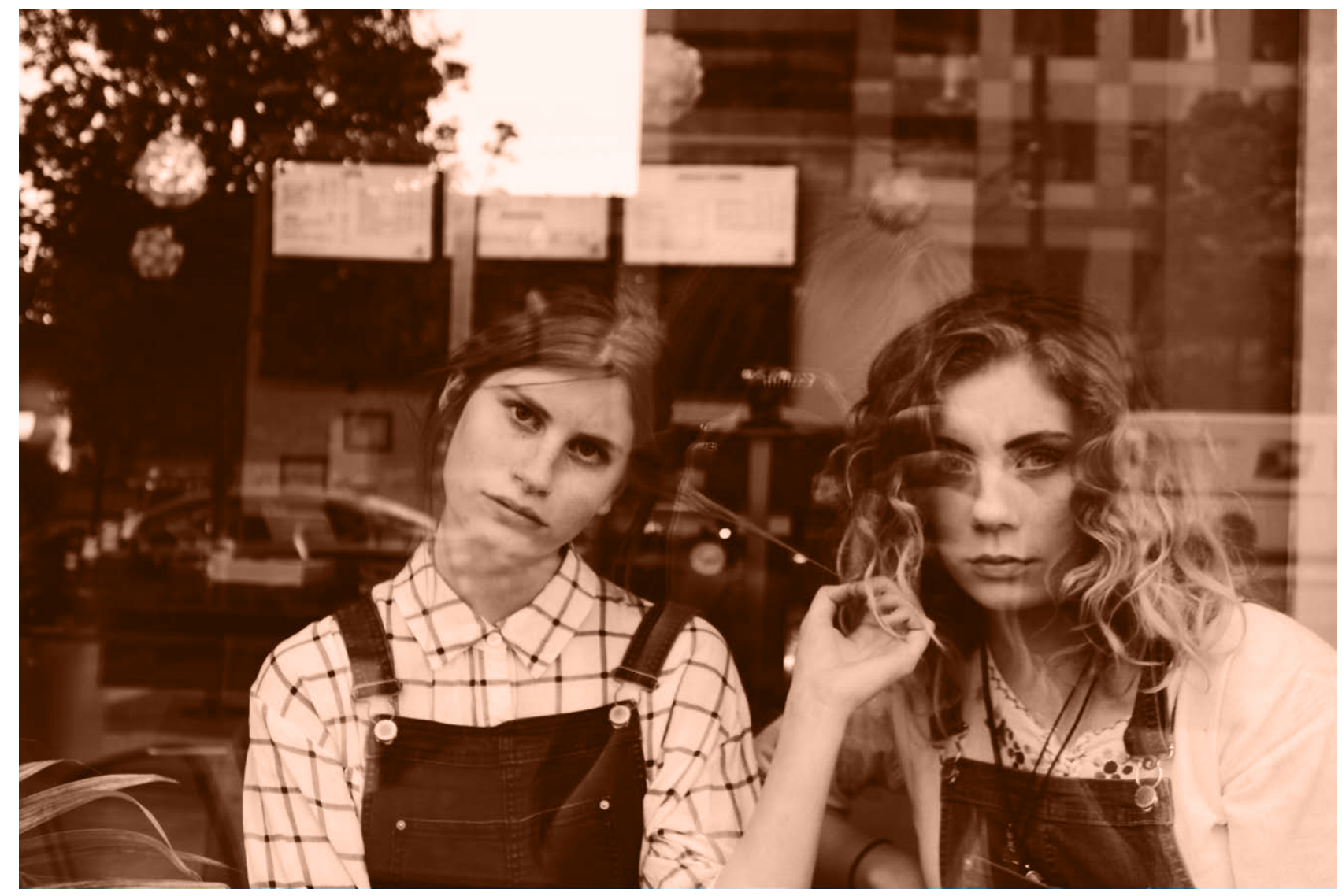

social relationships» (s. 2012). Denne definisjonen tek høgde for sosiale relasjonar, og avgrensar seg ikkje til ein geografisk stad. Forfattarane føreslår vidare at ein samanheng mellom tid og geografisk nærleik berre er naudsynt dersom ein ikkje har haldepunkter for sosiale relasjonar mellom dei avdøde, og at det er tilstrekkeleg med næreleik i tid i dei tilfella der ein har sterke haldepunkter for at personane kjende kvarandre. Det å kjenne nokon som tar livet sitt er assosiert med ei auka risiko for giennomført sjølvmord (Swanson \& Coleman, 2013), uavhengig av fysisk nærleik.

Som allereie nemnt påpeiker Niedzweidz et al. (2014) at det finst lite forsking på fenomenet, og at forskinga som finst er prega av ein manglande eintydig definision av denne type smitte. Dette gier det vanskeleg å samanlikne resultat på tvers av studiar.

\section{Korleis smittar sjølvmord?}

Det finst fleire teoriar om kvifor siølvmord smittar, men lite evidens (sjå t.d. Haw et al., 2013 for ei utgreiing av ulike psykologiske mekanismar). For at eit sjølvmord skal smitte må ein først anten indirekte (t.d. via media) eller direkte (t.d. ved at nokon dei kjenner) ha opplevd at nokon tek livet sitt. Imitasjon i kombinasion med modellering giennom sosial læringsteori er den vanlegaste teoretiske forklaringa på kvifor siølvmord smittar. Ved imitasion har ein vert eksponert for ein modell, og ein kopierer ofte, men ikkje alltid, siølvmordsmetoden (Niederkrotenthaler et al., 2012). Imitasjon blir kalla copy-cat sjølvmord eller Werthereffekten. Imitasjonseffektane blir sterkare dersom ein sjølv opplever å ha like eigenskapar eller slit med liknande ting som personen som tek livet sitt (Stack, 2005; Niederkrotenthaler et al., 2012). Effektane er òg sterkare dersom den som tek livet sitt er ein person ein ser opp til (t.d. ein kjendis), og dersom personen og siølvmordet blir glorifisert i ettertid. Innanfor sosial læringsteori tenkjer ein at sjølvmordet blir ein modell som viser siølvmord som ei akseptabel løysing på eit personleg problem hos ein særleg sårbar eller siølvmordsnær. Sterkt eksponerte og godt likte kjendisar blir dermed særleg potente modellar. Stack (2005) påpeiker òg at enkelte typar mediedekning av eit sjølvmord kan forsterke kjensler ein person allereie har rundt eit sjølvmord. Dersom reportasjen fokuserer på dei vanskane personen hadde, og desse liknar på det den sjølvmordsnære personen strever med, kan dette vere med på å legitimere sjølvmord og fjerne hemningar hos dei som allereie tenkjer på det.

Ein annan teori om kvifor sjølvmord smittar er via 
'assortative relating' (Joiner, 1999, som sitert i Haw et al., 2003). Innanfor dette rammeverket smittar ikkje sjølvmord på grunn av sosial læring eller imitasjon, men fordi folk har ein tendens til å omgåas andre menneske som er like ein siølv. Når det skjer eit sjølvmord i eit område vil det mest sannsynleg bu andre i området som har liknande sosiodemografiske variablar, og som difor har liknande sårbarhetar, og dermed liknande risiko for sjølvmord som den som tok livet sitt. Dette kan ein sjå døme på når sårbar ungdom omgås annan sårbar ungdom, eller ved sjølvmord på ei psykiatrisk avdeling.

\section{Kven er mest sårbar for smitteeffektar?}

Ein har undersøkt point clusters i ulike settingar: psykiatriske sjukehus, skolar (Callahan, 1996), fengsel, i urbefolkning, og i den generelle befolkninga (Niedzweidz et al., 2014). Det ser ut til å vere ein høgare risiko for fleire siølvmord over eit kortare tidsrom i institusjonar. I ei overvekt av studiane fann ein at unge vaksne under 35 hadde størst risiko for å bli påverka. I USA fann ein at ungdom og unge vaksne hadde $2-4$ gonger større risiko enn vaksne (Gould, Wallenstein, \& Kleinman, 1990, som sitert i Niedzweidz et al., 2014).

Når det gield kjønn ser ein same mønster som sjølvmordsåtferd elles: fleire menn enn kvinner giennomfører sjølvmord, medan kvinner har fleire forsøk (FHI, 2015; Haw et al., 2013). I ein litteraturgiennomgang av risikofaktorar og mekanismar for smitte, fann ein at det å vere mann, ungdom, ha ein historie med rusmisbruk, siølvskading eller ei psykisk liding, auka risikoen for å bli påverka av smitte (Haw et al., 2013). I cluster med berre kvinner var det meir sjølvskading og sjølvmordsforsøk, medan det var snakk om giennomførte siølvmord i cluster med berre menn. Ein veit likevel ikkje om dette er generelle risikofaktorar for sjølvmord, eller om desse risikofaktorane er spesifikke for smitte.

I eit innlegg på NSSF sin 10. nasjonale konferanse om selvmordsforskning og -forebygging presenterte Robinson (2019) modellen "circles of proximity» (sjå figur 1):

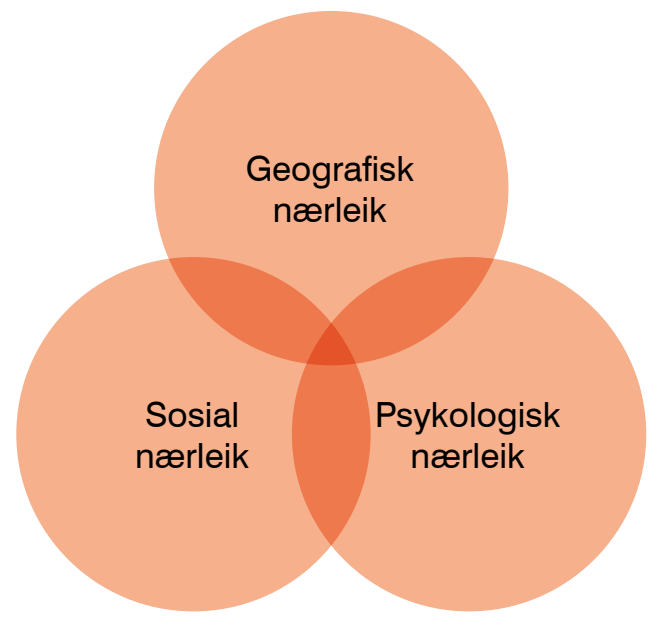

Denne modellen skildrar sårbarhet for smitte som eit resultat av geografisk-, sosial- eller psykologisk nærleik. Med geografisk nærleik meiner ein fysisk avstand til siølvmordet, t.d. å vere den som finn avdøde, eller ved at ein blir eksponert for følgiene av siølvmord t.d. ved å vere elev på same skule. Med sosial nærleik meiner ein at ein har ein relasion til avdøde. Med psykologisk nærleik meiner ein i kva grad personen relaterer seg til avdøde, t.d. giennom kulturelle eller subkulturelle forbindingar, t.d. at både avdøde og den sårbare har vert mobba, eller at ein ser på seg sjølv som i same livssituasion som avdøde. Denne modellen kan vere nyttig i samtalar med born og unge som ein er bekymra for, då den gir ein peikepinn på område som kan vere nyttige å kartlegge hos sårbar ungdom.

Heldigvis er smitteeffekter relativt sjeldne. Ein estimerer at $1-2 \%$ av siølvmord hos ungdom generelt kan forklarast utelukkande med smitteeffektar, med variasjon frå mindre enn $1 \%$ til $13 \%$ (Gould, Wallenstein, \& Kleinman, 1990, som sitert i Haw et al., 2013). I ei nyare studie frå Australia fann Robinson et al. (2016) at cluster utgiorde 5,6\% av alle sjølvmorda blant ungdom, og 2,3\% av alle siølvmord blant vaksne.

\section{Kva er det med tv-serien 13 Reasons Why som kan} fremme sjølvmordståferd hos ungdom?

Netflix og serieskaparane argumenterer for at serien er med på å bidra til openheit, debatt og å fjerne tabu, medan fagpersonar har kritisert serien for å mellom anna ikkje ta omsyn til forsking og kunnskap om siølvmord, og ikkje fokusere nok på hovudpersonen sine psykiske vanskar. Serien har blitt kritisert for å vere ei urealistisk skildring av eit siølvmord. Om ein leitar litt rundt på nettet så finn ein blogginnlegg frå fleire som har sett serien, og som identifiserer seg sterkt med hovudpersonen. I framstillingar av siølvmord der siølvmordet blir presentert som ei løysing på eit problem, er dette ein risikofaktor for smitte.

13 Reasons Why skildrar ei ung jente som føler seg utstøtt, som nettopp har flytta til byen, og som strever med å skape seg eit nettverk av nære venner. Ho opplever konfliktar som fører til brot i relasjonar til dei rundt ho, og fleire belastande livshendingar som mobbing og valdtekt. Ho snakkar i liten grad med dei rundt seg om vanskane ho opplever, verken med vaksne eller jamnaldrande. Serien illustrerer holet ein sjølvmordsnær ungdom kan falle ned i på ein måte som potensielt kan fremme identifikasjon med hovudpersonen. Eg tenkjer dermed serien kan legge grobotn for ei imitasjonseffekt blant enkelte unge som har det vanskeleg, og som samtidig identifiserer seg med hovudpersonen.

Anne Freuchen et al. (2012; Freuchen \& Grønholt, 2013) har forska på norske born under 15 år som tok livet sitt. Sjølv om hovudpersonen i 13 Reasons Why er eldre enn borna Freuchen forska på har ho fleire fellestrekk med desse borna. Hos eldre born ser ein 


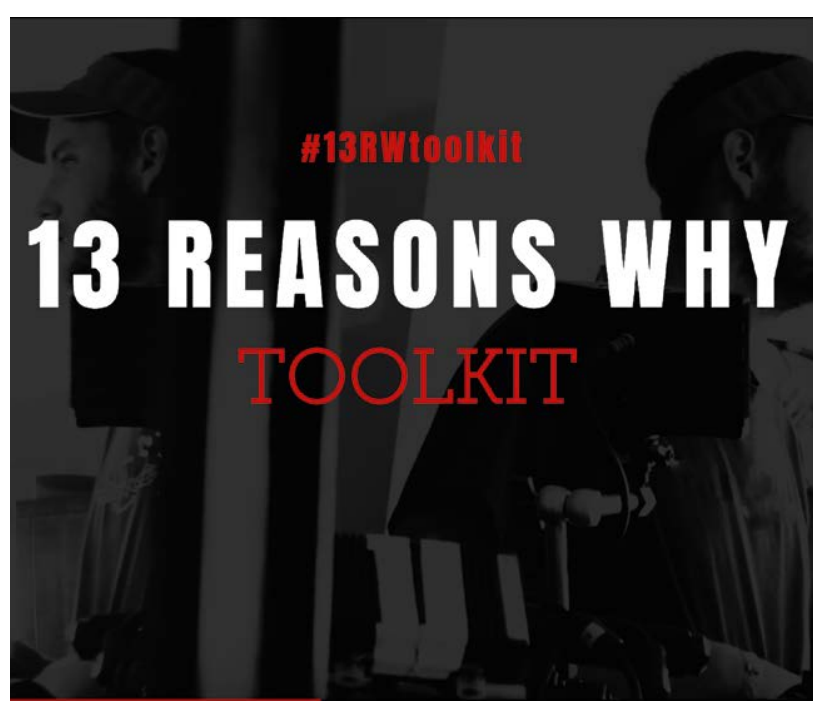

ofte meir typiske risikofaktorar for siølvmordsfare: psykiske lidingar, rusmisbruk, vanskar i familie, brot i nære relasjonar, alvorleg sjukdom, samt sjølvskading og tidlegare siølvmordsforsøk (Folkehelseinstituttet, 2015), men Freuchen et al. (2012) fann at depresjon og andre psykiske lidingar var mindre vanleg hos borna enn det er hos eldre ungdom og vaksne som tek livet sitt. Fleire av borna ho studerte var triste og viste teikn på sub-terskel depresjon, men berre $20 \%$ som hadde ei diagnostiserbar psykisk liding. Ho fann òg at ein større del av borna som tok livet sitt hadde opplevd eit vondt tap eller hadde vert i ein konfliktsituasjon dei ikkje klarte å løyse forut for siølvmordet, samanlikna med borna ho studerte som ikkje tok livet sitt. Ho fann òg at desse borna i mindre grad snakka med foreldra sine om ting som var vanskelege i liva deira. Borna som tok sitt eige liv vart ofte skildra som 'sårbare' av foreldra sine. I 13 Reasons Why er det ikkje tydeleg om personen har ei diagnostiserbar psykisk liding. Sjølvmordet ser i serien ut til å vere eit resultat av fleire belastande livshendingar, og ein utforskar i liten grad om det har ført til ei psykisk liding som ein kunne fått hielp for.

13 Reasons Why er sentrert rundt ei rekke kassettar der hovudpersonen har dedisert ein kassett til kvar person ho meiner er medverkande årsak til sjølvmordet. $43 \%$ av borna i studien til Freuchen og Grøholt (2013) skreiv sjølvmordsbrev. Desse breva skilte seg frå innhaldet i kassettane i 13 Reasons Why ved at hemnmotivet var lite framståande. Freuchen og Frøholt fann at borna i stor grad tok ansvar for valet dei hadde tatt, og uttrykte kiærleik til dei etterlatne, samt viste ei indre smerte og sårheit over valet dei hadde tatt. Døme på utsegn ho fann i breva ho studerte var: «Du betyr alt for meg», «det er betre om eg er død», «eg er lei meg for at eg var slem med deg», og «dette gier like vondt for meg som det gier for deg» (s. 7).
I vårt arbeid med sjølvmordsførebygging legg me sterk vekt på mestring og håp, at mange vanskelege situasjonar er forbigåande, og at ein kan få hjelp til andre mestringsstrategiar i tilfella der dei ikkje er det. Det som kan vere uheldig med denne serien er at den retter seg mot den gruppa som antakeleg er mest sårbare for smitteeffektar: born og unge (Robinson et al., 2016; Gould, Wallenstein, \& Kleinman, 1990, som sitert i Haw et al., 2013), og det kan for mange vere lett å kjenne seg att i hovudpersonen sine vanske. I tillegg viser serien at hovudpersonen blir møtt på ein lite hensiktsmessig måte når ho fortel ein vaksen på skulen om det ho strevar med. Hos sårbar ungdom som kjenner seg åleine kan dette sende eit signal om at det ikkje er hjelp å få. Dette bodskapet, i kombinasjon med sterke, emosjonelle situasionar mange born og unge kan kjenne seg att i, tenkjer eg kan auke faren for smitteeffektar. I tillegg til dette bryt serien med god pressefaglig etikk (World Health Organization, 2008; Norsk Presseforbund, 2006), og viser i grafisk detalj korleis ein kan ta livet sitt. Ein kan drøfte om underhaldningsprogram er underlagt pressefaglige etiske retningslinjer, men samanhengen mellom å vise sjølvmordsmetode og ei auke i bruk av same metode er godt dokumentert, så eg tykkjer likevel det er verdt å reflektere rundt kor stor grad av detaljar som er naudsynt for å få fram eit kunstnarisk poeng versus potensielle negative effektar. 13 Reasons Why vart opprinneleg publisert som bok i 2007, utan at boka genererte like mykje mediemerksemd med tanke på smitte. Det finst mange kunstnariske framstillingar av sjølvmord som ikkje er assosiert med smitte. Som tidlegare nemnt har ein noko kunnskap om kva type innhald i medieframstillingar som hemmar og fremmar smitte, men langt frå nok til at ein kan trekke skarpe konklusjonar om kvifor enkelte eksponeringar for enkelte personar eller grupper, på enkelte tidspunkt, ser ut til å henge saman med ei auke i siølvmordsåtferd, medan andre ser ut til å ikkje giere det. Det ser òg ut til å vere store individuelle forskjellar med tanke på korleis ungdom reagerer på innhaldet i serien. For enkelte kan det til og med tenkast at det fører til positive endringar. I eit intervju med forfattaren av boka på ei bloggside fortel han om henvendingar frå ungdomar som har lest boka som blir klar over måtar hovudpersonen kunne ha handla annleis i situasionen (Biedenham, 2015):

«They really pick up on who she was pushing away, even if she didn't know it at the time, and we only know, as readers, that that person cares about her. One of the greatest emails I got was from this 14-year-old girl who was in that position, and said at one point she got so upset at Hannah because she identified with her, because she wanted her to live. At some point, she had to turn it around and say, 'Okay, I can't be upset with her when I'm doing the same thing.'»

Ein skal vere varsam med å dra konklusjonar frå enkelthistorier, men denne fråsegna viser at risiko for, 
og beskyttelse frå, smitte ved siølvmord i ulike typar media er eit komplisert tema. Støtte for dette finn ein i ei undersøking av internettsøk om tema siølvmord før og etter 13 Reasons Why hadde premiere på Netflix. Ayers et al. (2017) fann ei samla auke på $19 \% 19$ dagar etter premieren. Den største auka var søk relatert til sjølvmordsåtferd (t.d. «korleis ta livet av seg sjølv»), samt søk etter hielpelinjer og søk relatert til folkeopplysning om sjølvmord (t.d. «sjølvmordsførebygging»). Dette funnet indikerer at serien har hatt ulik effekt på ulike sjåarar, og det er rimeleg å tenkje at det er stor individuell variasjon i korleis ulike framstillingar av sjølvmord påverkar sjølvmordsåtferd.

\section{Implikasjonar for praksisfeltet: Korleis kan ein førebygge smitte?}

Forskinga og teori viser at smitteeffektar ikkje rammar heilt tilfeldig. Ein tenkjer seg at det ved smitte ofte er snakk om ei underliggande risiko for siølvmord, som blir ytterlegare auka ved eksponering for temaet siølvmord. Men denne eksponeringa aukar ikkje likt for alle, og ein veit ikkje kva dei bakanforliggande mekanismane som gier at nokon får auka risiko, medan den for andre kan vere uendra eller til og med minke. Det kan t.d. vere at born og unge som allereie er i risiko for siølvmordsåtferd i større grad enn andre born oppsøkjer materiale som omhandlar tematikken. Det kan òg vere at personar som allereie tenkjer på sjølvmord og blir eksponert for temaet kan få senka terskelen for å giere tanke om til handling. Uavhengig av årsak tilseier erfaringane frå min jobb at mange born og unge som slit med sjølvmordstankar ikkje snakkar med vaksne rundt seg, og kan dermed vere vanskelege å fange opp. Av den grunn er det viktig å ha kunnskap om smitte, samt å ha verktøy for å avdekke og følgje opp personar der ein kjenner på ei dårleg magekjensle, eller der ein er usikker på korleis personen kan ha blitt påverka av eksponering for sjølvmord. Det er ikkje funne smitteeffektar av nøktern og sakleg presentasjon av sjølvmord og sjølvskading (Helsedirektoratet, 2017). Å gie informasjon til fleire enn dei ein tenkjer er i faresona er ein viktig del av det førebyggande arbeidet. I denne delen av artikkelen vil eg gie eit døme på korleis ansvarleg handsaming av sjølvmord i media kan vere med på å førebygge sjølvmord, samt vise til verktøy for å handsame smitte og følgie opp born og unge ein er bekymra for.

\section{Ansvarleg handsaming av sjølvmord i media kan førebygge sjølvmord}

På bakgrunn av kunnskap om smitteeffektar har Verdens helseorganisasjon utvikla retningslinjer for korleis media bør omtale sjølvmord (World Health Organization, 2008). Ein anbefaler at ein unngår detaljerte skildringar av metode eller stad, at ein unngår språk som sensasjonaliserer eller normaliserer sjølvmord, at ein ikkje presenterer det som ei løysing

på problem, at ein er varsam med overskrifter og bruk av bilete eller video, og at ein er særs varsam ved rapportering av berømte menneske som tek livet sitt. Ein anbefaler òg at ein nytter ein reportasje om sjølvmord til å opplyse lesarane om at siølvmord sjeldan er utløyst av ein enkelt faktor, og at ein legg vekt på håp og alternative løysingar samt kor ein kan få hjelp dersom ein slit med sjølvmordstankar.

\section{Ansvarleg mediehandsaming: eit døme}

Eit døme på at ansvarleg mediehandsaming kan førebygge sjølvmord var då Kurt Cobain tok livet av seg i 1994. Cobain (frontfigur i Nirvana) var ein person mange born og unge, som på ein eller annan måte kjente seg på utsida av samfunnet, identifiserte seg med. Då han tok livet sitt var det mykje som låg til rette for at smitteeffektar kunne oppstå. I ein oppfølgingsperiode på 7 veker etter sjølvmordet var det 24 siølvmord i Seattleområdet, men berre

Det ser ut til at å omtale sjølvmord $i$ media kan vere både positivt og negativt, avhengig av korleis ein presenterer tema. eitt av dei kunne kategoriserast som eit reint imitasjonssiølvmord (Jobes, Berman, O'Carroll, Eastgard, \& Knickmeyer, 1996). Det var ingen auke i førekomsten av sjølvmord samanlikna med åra før. Eit studie av sjølvmord blant ungdom i Australia i månaden etter siølvmordet fann ein reduksion i sjølvmord i dei første fem, ti og femten dagane etter siølvmordet, samt inga auke i dødsfall med den aktuelle metoden (Martin \& Koo, 1997).

Kva giorde ein riktig her? Seattle Crisis Center hadde ein god dialog med media, der ein oppmoda til å skilje mellom artisten Cobain og privatpersonen Cobain. Artisten Cobain vart presentert som ein dyktig og elska musikar, medan ein fokuserte på at privatpersonen Cobain hadde levd eit turbulent liv, hadde ei rekke psykiske lidingar som førte til at han giorde ei handling som fekk store konsekvensar for dei etterlatne. På ei minnestund to dagar etter sjølvmordet, der 7000 personar møtte opp, oppmuntra ein dei ramma til å ta vare på seg siølv og kvarandre, samt til å ta kontakt med krisesenteret dersom ein hadde behov for det. Krisesenteret fekk ei sterk auke i henvendingar, utan at talet på siølvmord giekk opp. I tillegg til dette giekk kona til Cobain ut i media og viste sine sterke kjensler rundt det som hadde skiedd. Ho gav fleire interviu der ho ufiltrert viste kva hans siølvmord hadde giort med henne: ho viste sinne, bebreida seg siølv, og var trist.

Det ser ut til at å omtale sjølvmord i media kan vere både positivt og negativt, avhengig av korleis ein presenterer tema. Norsk presseforbund har på sine 
nettsider publisert ein rettleiar for omtale av sjølvmord (Norsk Presseforbund, 2006). I denne rettleiaren uttalar Lars Mehlum (leiar for Nasjonalt senter for selvmordsforskning og -forebygging) følgjande: «Å fokusere på selvmord som en utfordring for fellesskapet og som et samfunnsproblem vi kan giøre noe med, vil være gunstig. Det har vist seg at mer omtale av psykiske lidelser giør dem mindre stigmatiserende. Media må også søke å formidle håp, som er en meget sentral dimensjon når det gielder selvmord» (s. 4). Det er med andre ord ingen grunn til at media treng ha berøringsangst for temaet siølvmord, så lenge ein følgier dei ovanfor nemnte presseråda.

\section{Verktøy for å handsame smitte}

Få studiar har dokumentert effekten av tiltak for å hindre smitte etter siølvmord (Callahan, 1996; Cox et al., 2012; Robinson et al., 2016). I ein litteraturgiennomgang skriv Cox et al. (2012) at følgjande strategiar potensielt kan vere verksamme: å utvikle ein prosedyre eller handlingsplan i lokalsamfunnet, psykoedukasion om siølvmord, individual- og gruppeterapi til born og unge som er ramma, avdekke personar som har høgare risiko, ansvarleg handsaming i media, samt fremme helse og velvere i samfunnet. Helsedirektoratet (2017) har gitt ut eit rettleiande materiell for kommunane om førebygging av sjølvmord og siølvskading. I dette materiellet gir dei følgiande råd:

«Samtlige tiltak som iverksettes bør giøres i nær samforståelse og etter avklaring foretatt med etterlatte, der tiltakene blir iverksatt for å hindre smitte etter et giennomfort selvmord.

- Vær oppmerksom på personer med økt risiko, dette kan være personer:

- med psykiske plager, som direkte eller indirekte har vært eksponert for selvmord

- som tidligere har utført selvmordsforsøk

- som har mange belastende livshendelser

- som har en nær relasjon til den som tok sitt eget liv

- som er i en situasion at han/ hun har kranglet med /mobbet den som har tatt sitt eget liv

- Få klarhet i de faktiske forhold og unngå spekulasioner og ryktespredning.

- Gi støtte til den berørte familien eller etterlatte.

- Gi nøktern informasjon, ikke bli for detaljert.

- Informer ikke om tema i store forsamlinger, tilrettelegg for å samle personer i naturlige grupper.

- Gjør informasjon om hvor man kan motta hielp tilgiengelig.

- Tilrettelegg for et samarbeid med kommunens helse- og omsorgstieneste og spesialisthelsetjenesten.»
I tillegg har RVTS Øst omsett og tilrettelagt ei verktøykasse for førebygging av smitte direkte knytt til serien 13 Reasons Why. Dette verktøyet kan ein finne på rvtsost.no/aktuelt/verktoykasse-for-forebygging-avsmitteeffekter.

Dersom ein ynskjer å ta opp tema sjølvmord med born og unge, til dømes i eit klasserom, er det anbefalt at ein føl dei same prinsippa som dei presseetiske retningslinjene. I tillegg til dette er det viktig å skape ein kultur på skulen der ein ikkje held på løyndomar når det gield tema som sjølvmord og siølvskading. Dette gield sjølv om ein har blitt bedt om å halde det hemmeleg, og sjølv om det kan føre til eit relasjonsbrot. Sjølvskading og sjølvmordstankar er eit teikn på at ein ven treng meir hjelp enn ein åleine kan gie, og det finst mange som både kan og vil hielpe. Skuleleiar har ansvar for at det finst prosedyrar for korleis ein taklar denne type situasjonar.

Det er viktig å gie informasjon om kor ein kan få hielp. Rektorane i Trondheimsskulen gav i sitt skriv klar og tydeleg informasjon om kor ein kan søkje hielp dersom ein er bekymra. I tillegg til det offentlege hjelpeapparatet har frivillige organisasionar som Mental Helse og Kirkens SOS hielpetelefonar ein kan ringe.

Foreldre og pårørande har òg ei sentral rolle i det sjølvmordsførebyggande arbeidet. Helsedirektoratet har gitt ut nasionale rettleiar for å ivareta etterlatne etter siølvmord (2011) og for pårørande (2017a). Når det gield pårørande og etterlatne finst det mange frivillige organisasionar med god kompetanse på dette, mellom anna Landsforeningen for etterlatte etter selvmord (LEVE), Landsforeningen for pårørende innen psykisk helse (LPP), Pårørendesenteret, og Mental Helse for å nemne nokre få.

Det er viktig å vere oppmerksam på og følgie opp born og unge som har det vanskeleg. For å giere dette er det viktig å vite noko om vanlege risikofaktorar, samt ha kompetanse på å giennomføre avdekkande samtalar. Forsking peiker i retning av at det å spørje ungdom om sjølvmordstankar og sjølvskading ikkje vekker tankar om å skade seg verken hos ungdom flest eller hos risikoutsett ungdom (Dazzi et al., 2014). Eigen klinisk erfaring tilseier at mange syns det er vanskeleg å ta opp temaet på eigenhand, og syns det er trygt og godt å bli spurt direkte. Det finst fleire gode verktøy med råd til samtalar, mellom anna i det rettleiande materiell for kommunen om førebygging av siølvmord og siølvskading frå Helsedirektoratet (2017) og på helse-vest.no/selvmord. Når det gield sjølvmord og skule har RVTS Vest utvikla nettsida livetpatimeplanen. no, der ein kan finne meir informasjon om korleis ein kan hjelpe born og unge som skadar seg sjølv eller har sjølvmordstankar. Utdanningsdirektoratet (2019) har òg ei nettside med informasion om sjølvmordsførebygging retta mot skule. Mange lokale kriseteam har òg erfaring med tematikken. Siølv om smitte er eit god dokumentert fenomen finst det òg informasion om korleis ein kan jobbe for å førebygge og forhindre det. 


\section{REFERANSAR}

Ayers, I. W., Althouse, B. M., Leas, E. C., Dredze, M., \& Allem, IP. (2017). Internet searches for suicide following the release of 13 reasons why. IAMA Intern Med, 177(10), 1527-1529.

Bateson, I. (2012). The final leap. Suicide on the Golden Gate Bridge. London: University of California Press.

Biedenham, I. (2015, April 21). Q\&A: 'Thirteen Reasons Why' author Tay Asher on bullying and teen suicide prevention. Henta frå: https://ew.com/ article/2015/04/21/thirteen-reasons-why-jay-asher-bullying-suicide/.

Callahan, I. (1996). Negative effects of a school suicide postvention program--a case example. Crisis, 17(3), 108-115.

Cox, G. R., Robinson, I., Williamson, M., Cheung, Y. T., \& Pirkis, I. (2012) Suicide clusters in young people: evidence for the effectiveness of postvention strategies. Crisis, 33(4), 208-214

Dazzi, T., Gribble, R., Wessely, T. \& Fear, N. T. (2014). Does asking about suicide and related behaviours induce suicidal ideation? What is the evidence? Psychological Medicine, 44(16), 3361-3363. DOI: 10.1017/Soo33291714001299.

Etzersdorfer, E., \& Sonneck, G. (1998). Preventing suicide by influencing mass-media reporting. The Viennese experience 198-80-1996. Archives of Suicide Research, 4, 67-74.

Ferguson, C. I. (2019). 13 Reasons Why Not: A methodological and meta-analystic review of evidence regarding suicide contagion by fictional media. Suicide and life-threatening behavior, 49(4), 1178-1186.

Folkehelseinstituttet. (2015). Selvmord og selvmordsforsøk - faktaark med helsestatistikk. Henta frå: https://www.fhi.no/fp/psykiskhelse/selvmord/ selvmord-og-selvmordsforsok---fakta/.

Freuchen, A. \& Grøholt, B. (2013). Characteristics of suicide notes of children and young adolescents: An examination of the notes from suicide victims 15 years and younger. Clinical Child Psychology and Psychiatry, o(o), 1-13.

Freuchen, A., Kielsberg, E., Lundervold, A. I. \& Groholt, B. (2012). Differences between children and adolescents who commit suicide and their peers: A psychological autopsy of suicide victims comparted to accident victims and a community sample. Child and Adolescent Psychiatry and Mental Health, $6(1)$.

Gould, M., Jamieson, P., \& Romer, D. (2003). Media contagion and suicide among the young. American behavioral scientist, 46(9), 1269-1284.

Gould, M. S., Wallenstein, S., \& Davidson, L. (1989). Suicide clusters: A critical review. Suicide and life threatening behavior, 19(1), 17-29.

Haw, C., Hawton, K., Niedzwiedz, C. \& Platt, S. (2013). Suicide clusters: A review of risk factors and mechanisms. Suicide and life-threatening behavior, 43(1), 97-107.

Hawton, K., Simkin, S., Deeks, I. I., O'Connor, S., Keen, A., Altman, D. G. Philo, G. Bulstrode, C. (1999). Effects of a drug overdose in a television drama on presentations to hospital for self poisoning: time series and questionnaire study. BMI, 10(318), 972-977.

Helsedirektoratet. (2011). Etter selvmordet - veileder om ivaretakelse av etterlatte ved selvmord (IS-1898). Oslo: Direktoratet.

Helsedirektoratet. (2017). Forebygging av selvskading og selvmord i kommunen. Henta frå: https://helsedirektoratet.no/nyheter/forebygging-av-selvskading-og-selvmord-i-kommunen.

Helsedirektoratet. (2017a). Veileder om pårorende i helse- og omsorgstienesten (IS-2587). Oslo: Helsedirektoratet. Henta frå: https://helsedirektoratet.no/retningslinjer/parorendeveileder.

Jobes, D. A., Berman, A. L., O'Carroll, P. W., Eastgard, S. \& Knickmeyer, S (1996). The Kurt Cobain suicide crisis: Perspectives from research, public health and news media. Suicide and Life-Threatening Behavior, 26(3), 260-271.

Martin, G. \& Koo, L. (1997). Celebrity suicide: Did the death og Kurt Cobain influence young suicides in Australia? Archives of Suicide Research, 3(3), 187-198
Marzuk, P. M., Tardiff, K., Hirsch, C., Leon, A. C., Stajic, M., Hartwell, N. \& Portera, L. (1993). Increase in suicide by asphyxiation in New York City after the publication of Final Exit. New England Journal of Medicine, 329 1508-1510.

Misje, H. K. \& Wold, O. M. (2017, 14. mai). Derfor slo Trondheim kommune alarm om selvmord. VG. Henta frå: https://www.vg.no/nyheter/innenriks/i/ dKoXX/derfor-slo-trondheim-kommune-alarm-om-selvmord.

Niederkrotenthaler, T., Fu. K., Yip, P. S. F., Fong, D. Y. T., Stack, S., Cheng, Q. \& Pirkis, I. (2012). Changes in suicide rates following media reports on celebrity suicide: a meta-analysis. I Epidemiol Community Health, 66, 10371042.

Niderkrotenthaler, T., Voracek, M., Herberth, A., Till, B., Strauss, M., Etzersdorfer, E., ... \& Sonneck, G. (2010). Role of media reports in completed and prevented suicide: Werther v. Papageno effects. The British Journal of Psychiatry, 197, 234-243.

Niedzweidz, C., Haw, C., Hawton, K. \& Platt, S. (2014). The definition and epidemiology of clusters of suicidal behavior: a systematic review. Suicide and Life-Threatening Behavior, 44(5), 569-581.

Norsk Presseforbund. (2006). Veileder for omtale av selvmord Henta frå: http://presse.no/wp-content/uploads/2014/10/Revidert-veileder-for-omtaleav-selvmord.pdf.

Philips, D.P. (1974). The influence of suggestion on suicide: substantive and theoretical implications of the Werther effect. American Sociological Review, 39(3), 340-354

Robinson, I. (2019, april). Youth suicide prevention across settings. Munnleg presentasion på NSSF sin 10. nasjonale konferanse om selvmordsforskning og -forebygging, Stavanger, Noreg.

Robinson, I., Too, L. S., Pirkis, I. \& Spittal, M. I. (2016). Spatial suicide clusters in Australia between 2010 and 2012: a comparison of cluster and non-clus ter among young people and adults. BMC Psychiatry, 16(417).

Røed, R. (2017, 27. mai). Bekymring etter flere selvmord og selvmordsforsøk på Lillehammer. VG. Henta frå: https://www.vg.no/nyheter/innenriks/i/ 99ok1/bekymring-etter-flere-selvmord-og-selvmordsforsoek-paa-lillehammer.

Sinyor, M., Schaffer., A., Nishikawa, Y., Redelmeier, D. A.,

Niederkrotenthaler, T., Sareen, I., Levitt, AI, Kiss, A. \& Pirkis, I. (2018). The association between suicide deaths and putatively harmful and protective factors in media reports. CMAI, 190(30), 900-907.

Stack, S. (2005). Suicide in the media: a quantitative review of studies ased on nonfictional stories. Suicide and Life-Threatening Behavior, 35(2), 121-133.

Swanson, S.A., \& Colman, I. (2013). Association between exposure to suicide and suicidality outcomes in youth. CMAI, 185 (19), 870-877.

Utdanningsdirektoratet. (2019). Forebygging av selvskading og selvmord. Henta frå: https://www.udir.no/kvalitet-og-kompetanse/beredskap-og-krisehandtering/skolens-selvmordsforebyggende-arbeid/.

World Health Organization. (2008). Preventing suicide: A resource for media professionals (rapport). Geneva: WHO Press.

Ystgaard, M. (1997). Selvmord blant ungdom - er det smittsomt? Suicidologi, 2(3), 12-14.

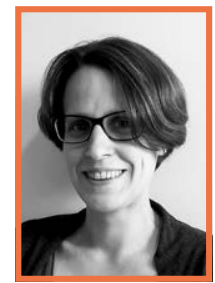

ÅSE LUNDEGAARD MATTSON jobber som psykolog ved Ressurssenter om vald, traumatisk stress og sjølvmordsførebygging i region Vest, med spesiell interesse for temaene sjølvmordsførebygging og traumer. 